\title{
JOURNAL.RU
}

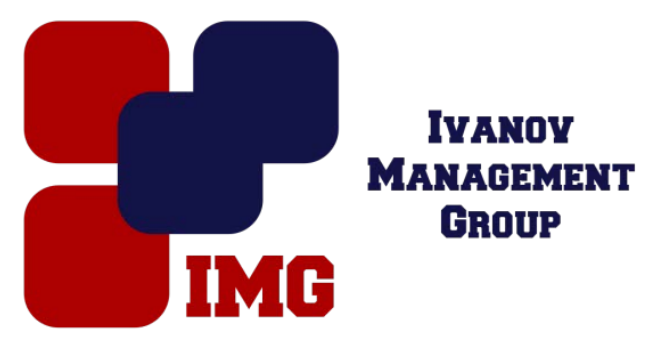

Моргунова Е.В. Муниципальное автономное общеобразовательное учреждение «Гимназия № 30» Курган, Россия

doi: 10.18411/lj-31-01-2017-3-08

idsp 000001:lj-31-01-2017-3-08

\section{Организация школьного физкультурно - спортивного клуба для учащихся}

\section{Аннотация}

Забота о поддержании здоровья школьников, повышение показателей физической подготовленности, предотвращение дефицита двигательной активности и определили выбор направления деятельности школьного физкультурно-спортивного клуба: воспитание и здоровьесбережение в образовании.

Ключевые слова: школьный физкультурно - спортивный клуб, учитель, ученик, образование, внеурочная и урочная деятельность.

По истечению 5 лет процесс создания Школьного Спортивного Клуба (далее ШСК) набирает свои обороты и, по словам министра образования Ольги Васильевой уже почти половина образовательных организаций имеет свои ШСК по России. Для города Кургана создание школьных физкультурно - спортивных клубов (далее ШФСК) остается актуальным. Идея создания клубов - не нова и чётко структурирована. Общее руководство деятельностью ШФСК осуществляет методическое объединение учителей физкультуры. Учителя физкультуры содействуют реализации инициатив воспитанников во внеучебной деятельности: привлекают школьников к организации физкультурно спортивной работы в гимназии, создают условия для их реализации. Совет клуба входят ученики - активисты физкультурной работы, участники школы общественного инструктора, вожатые школы Российского движения школьников, которые изучают интересы и потребности школьников в сфере внеурочной деятельности, являются помощниками в проведении мероприятий. Деятельность ШФСК направлена на решение следующих задач: создание условий, содействие оздоровлению и совершенствование физической подготовленности, организация Школы общественного инструктора, популяризация ВОШ, ВФСК ГТО и ЗОЖ. Модель ШФСК «Тридцаточка» 
уникальна, так как адаптирована к конкретным условиям гимназии (два спортивных зала, зеркальный и тренажёрный залы). В работе ШФСК «Тридцаточка» выделено четыре блока: «Школа Общественного Инструктора», «Спортивные секции», «Физкультурно-спортивные мероприятия» и «Олимпиадное движение», которые имеют конкретные педагогические цели, задачи и формы. Таким образом, мы выстроили функциональную взаимосвязь между формами организации физического воспитания, содержанием работы блоков и методами их проведения во время урочной и внеурочной деятельности. 